\title{
Rozelle
}

\section{John Williams}

To her audiences of the 1960s, who knew it as slum housing for postwar migrant labour, Edna Everage, Australia's 'La Dame aux Gladiolas', lampooned Rozelle as the new resort of Australia's aspiring literati. More recently, Melbourne demographer Bernard Salt described the suburb as 'chick-city', a reference to the disproportionately large number of never-married female residents aged 24 to 35 recorded by the 2001 census, outnumbering local men in the same age group 1.26 to $1 .{ }^{1}$ Within Rozelle's retail hub, the recent proliferation of nail technicians, beauty salons, interior decorators, patisseries, and alfresco cafes avows not only that the suburb has gentrified, but also that it's chic.

Variously known in its history as Balmain West and Balmain South, Rozelle occupies the south-western portion of a hilly inner-harbour peninsula west of Millers Point and north of Pyrmont and Glebe. The western slope of the main ridge joins Iron Cove and the eastern side slopes to the contiguous Johnstons, White, and Rozelle bays.

The highest elevation on the Rozelle ridge is 42.7 metres above mean high tide, from which point there is a spectacular view of central Sydney and the Anzac (formerly Glebe Island) Bridge. Statues of an Australian and a New Zealand soldier of the Great War, in solemn 'rest on arms reverse' position, guard the Rozelle end of the bridge, which is the gateway to Rozelle from the city.

Rozelle originally formed part of the 'half-a-thousand acres' that Governor John Hunter granted to the colony's principal surgeon, William Balmain, in 1800. The first recorded use of the name Rozelle Bay for the southernmost inlet of Johnstons Bay is 1875. In colonial India, 'rozelle' was an Anglicisation of rose saille, the French for red sorrel, which was an ingredient that the British used in jam, but there's no evidence of the herb's past cultivation or commercial use in this part of Sydney. The choice of the name Rozelle for the southwest part of the peninsula is attributed to the colonial Postmaster-General of 1892, who named the suburb's planned new post office after the nearby bay.

Road transit to Rozelle from the city was via the Balmain Road turnoff at Parramatta Road, Petersham, until the Pyrmont Bridge Company constructed a toll bridge that linked Pyrmont to Glebe Island across Johnstons Bay and opened to traffic in 1857. As it was built of blackbutt timber, this first structure was fittingly named Blackbutt Bridge. The landmark cable-stayed bridge that now spans Johnstons Bay opened in 1995 and was officially named Anzac Bridge on Remembrance Day 1998. Although the electrical swing-span Glebe Island Bridge of 1903, which the Anzac Bridge replaced, is now closed to vehicular and pedestrian traffic, the older bridge is viewable from the footway of the new.

At the 2006 census, the suburb's residential population numbered 7,719, with 48 per cent male and 52 per cent female. The percentage of residents aged 65 and over is 6.3, just less than half the national average of 13.3 per cent, meaning Rozelle has evolved as a young people's suburb. 
In common with others across inner Sydney, residents of Rozelle are religiously disinclined. An increasing proportion (41 per cent in 2006) either rejects the option of answering the census question on religion or indicates 'agnostic' or 'no religion'.

\section{Origins}

Rozelle's prehistory is a veiled one. As remnants of Aboriginal middens, which may be as old as 4,500 years, have survived on various parts of the Balmain peninsula, the Wangal band of the Dharug or Eora language group may be presumed to have inhabited Rozelle, as well as other areas south of the Parramatta River from the Balmain peninsula west to Auburn and Silverwater. The catastrophic epidemic of smallpox among Sydney's Aboriginal people that began in 1789 is known to have decimated the Cadigal band in the eastern and northern parts of Sydney. It seems improbable that so insidiously contagious a disease would not also have spread to the neighbouring Wangal people, as they too would have had no immunity.

While the Dharug-Eora people had lived in the Sydney area for at least 10,000 years before European settlement, the period of Wangal habitation is unknown. In 2004, following a change in the boundaries of the Leichhardt area and in recognition of coastal Sydney's Aboriginal history, Leichhardt Council, in consultation with the Local Metropolitan Land Council, adopted Aboriginal names for its ward structure. Wangal/Rozelle-Lilyfield was the name chosen for the ward centred on Rozelle. People living in Rozelle who identified themselves as being of Australian indigenous descent numbered 51 in the 2006 census.

Until 1860, Rozelle was sparsely populated with Europeans but, from 1860 to 1882, its frontier character rapidly subsided as land subdivision, speculation and sales surged. From 1880 to 1882 the overall peninsular population more than doubled from 8,000 to 16,928.

This transformation was attributable to an 1858 decision made by the judicial bench of the British House of Lords, which authorised the trustees of John Borthwick Gilchrist (1759-1841) to sell peninsular land that was still in their possession. William Balmain's heirs had contested the transfer that Balmain had made to Gilchrist in 1801, only 15 months after he was first granted the land. At that time, Gilchrist was in service to the East India Company at the College of Fort William, Calcutta (modern-day Kolkata), and becoming a noted Indologist.

David Ramsay was one early speculator. Ramsay's family had owned Dobroyd (now Haberfield) and he lived at nearby Kalouan, a house located at the southern side of the mouth of Long Cove Creek, close to where Broughton Hall now stands. Another was solicitor and artist George Penkivil Slade, after whom Slade Street, Rozelle, is named. Slade and Ramsay were related, both men having married descendents of Prosper de Mestre.

\section{Alfred Hancock, 'father of Rozelle'}

Alfred Hancock was a Londoner who migrated to Sydney in the late 1850s. Between 1867 and 1880, he purchased large parcels of local land. William Henry Paling, piano importer and alderman and mayor of Petersham, Louis Foucart MD, superintendent of Sydney's quarantine 
station, and Ferdinand Reuss, architect, builder and surveyor, were other speculators who joined Hancock's enterprise.

In his role of estate agent, Hancock used the advertising slogan 'Homes for the People' until 1907. His target market was working men, to whom he sold some 1,600 plots at $£ 4$ deposit and 21 quarterly instalments of $£ 2$. He further offered to supply timber at 10 shillings weekly. His strategy of achieving a large turnover of small building plots, sold at modest prices, enabled people of limited financial means to become freeholders.

Hancock served as an alderman of Balmain from 1873 to 1882 and again from 1884 to 1886, an opportunity that he probably used to minimise infrastructure costs associated with the provision of roads, drainage and open space in his subdivisions. Mertonville, the Balmain house that Hancock and his family occupied at Elliott, Beattie, and Lawson streets (now a public reserve), was, like many of the dwellings that sprang up on his estates, constructed of weatherboard and corrugated iron.

Rozelle is unique for its patterns of street names. One suite of these names has links with Hancock and his commercial partners: Alfred and Percy, after Hancock's sons; Charlotte and Elizabeth, after his daughters; and Maney, after Paling's brother-in-law, Andrew. Another suite has names associated with heroes of the Napoleonic wars: Nelson; Merton after Nelson's seat at Merton Place in a Surrey village; Hamilton, after Nelson's mistress; and Wellington, Waterloo and Cambridge.

\section{Transport}

Its proximity to a onetime working port enabled ferries to serve Rozelle, which had (at least) two public wharves. Located at the foot of Mansfield Street (where there is a nearby hotel of the same name), Bald Rock was the popular wharf for Rozelle's White Bay side. Until the Balmain Electric Light Company constructed its powerhouse at Iron Cove, a public wharf also operated near the foot of Margaret Street (which was possibly included in a city ferry route that operated from Long Cove Creek, one of Iron Cove's tidal tributaries, which was partially navigable, even into the early twentieth century).

Horse-drawn omnibuses initially provided public road transit from the city to Balmain, as well as to Ryde. Both routes included Rozelle and each was highly circuitous owing to the hilly peninsular geography. Because their routes passed nearby public wharves and their timetables coordinated with the city ferry timetables, the omnibuses complemented the later steam trams which carried passengers from the city via Forest Lodge. The steam trams were introduced in 1892 and their lines were electrified in the early twentieth century. The electric trams were quickly phased out after 1958 and gas-powered air-conditioned buses now ply routes to the city via Glebe, Norton Street, Leichhardt, and the Anzac Bridge.

\section{Industrialisation and its legacy}

By 1865, Dr George Robinson Elliott, in company with his brothers, Frederick and James, had acquired a site on the Iron Cove foreshore where they established Australia's first factory for 
chemicals, pharmaceuticals, and later glassworks. In 1892, William Lever acquired land adjacent to White Bay. Here in 1897 Lever Brothers Limited established a factory that extracted oil from copra cultivated on the firm's coconut plantations in the Solomon Islands, which was then shipped to Liverpool in England. The plant began manufacturing glycerin and Sunlight Soap.

Abattoir operations at Glebe Island began in 1860 and continued until 1912 when they were moved to Homebush. Reclamation of the mangrove swamps that flourished on both sides of the island began in 1895. The cultural and medical mindset of late-nineteenth-century industrial progress saw the mangroves not as essential wetland ecology but as 'fever beds' that were home to disease and stench spread by effluent from the abattoirs. The swags of noxious industries that the abattoirs spawned added to marine pollution.

Animal carcasses provided livelihoods in offal- and tripe-dressing, as well as cheap soap and candle manufacture. Beef or mutton offal and honeycomb tripe were inexpensive and - if properly prepared - palatable sources of protein that were considered a suitable diet for workers and housewives needing muscle-power. Candles and soap were made from the tallow and gelatin extracted from carcass refuse.

The Balmain Power Station at Iron Cove, which commenced generation in 1909, was followed by the White Bay Power Station, which became fully operational in 1917. By 1922, construction of the Glebe Island Grain Silos and railway sidings had reached completion, and Rozelle's eastern foreshore was the node of Australia's coal and timber industry.

Although less polluting, millet broom and brush making was a hazardous industry which sprang up in suffocating double-storey sheds clad in corrugated iron that were scattered across Rozelle's streets and laneways. Rebecca Grubmeier's Commonwealth (previously Federal) Brooms factory at 84 Foucart Street was one such example. The previous owner of the site began using it as a foundry in 1881, but when the colonial recession peaked in 1894, the mortgagors not only foreclosed, they also attempted to bankrupt the mortgagee.

Although Alfred Hancock claimed that proximity to heavy industry and expanding tramways was a sound economic reason for investing in Rozelle, the rapid degradation of environmental amenity and quality of social life eroded the value of such investment. Dilapidation was the legacy of the pollution from Rozelle's coal-fired powerhouses, sawmills and drying kilns, steam locomotives, steamships and foundries. The blight of dust, blown from coal stockpiled for ships' bunkers or holds, contributed to the process, along with sulphurous and other acidic fumes from Elliott Brothers' plant. Washhouse coppers, kitchen stoves, and domestic fireplaces, all fueled by coal or wood, were further sources of atmospheric pollution.

\section{Parks and public space}

Open space remains a contentious issue in contemporary local politics. Historically, when Rozelle's population was denser, the situation was worse. Provision of recreation grounds depended on reclamations of land at Rozelle Bay, White Bay and Iron Cove. Indeed, the White Bay Power House site, together with reclamations north of Whites Creek, was initially reserved 
for open space in 1899. Until Balmain Municipality resumed King George Park in 1912 as part of Iron Cove reclamation, Easton Park, established in 1890, which also adjoined the Rozelle Bay swamps, served as Rozelle's sole recreational ground. William Lever was renowned for progressive labour welfare, and the Sunlight Soccer Club was possibly formed within two months of his 1914 visit to Balmain. However, when Lever Brothers sought to develop land for the use of their workers' sports and welfare association, they had to look to Drummoyne.

O'Connor Reserve, an irregularly shaped park located on the south-eastern side of Victoria Road, is named in honour of the late Richard O'Connor, who was a lifetime resident of Rozelle and the last mayor of the Balmain Municipal Council, which was abolished in 1946. The Evans Street tram siding had occupied this site. A steelworks would likely have replaced the siding had the former council not protested to the McKell Labor government of New South Wales that Rozelle was already an over-industrialised and over-populated suburb starved of parkland.

\section{Civic quality}

In spite of the stigma of an ugly slum, Rozelle was blessed with a small but remarkable collection of public buildings. The oldest of these is St Thomas's Church of England, designed by Edmund Blacket in 1874. This was built, and later extended, in an early English Gothic style. Blacket \& Son designed the adjacent rectory, constructed in 1882, in Victorian filigree style.

The spacious St Joseph's Catholic church (1906) with its distinctive French-inspired fleche dominates the south-eastern side of Victoria Road. St Joseph's presbytery in nearby Quirk Street is styled in free Victorian Gothic, possibly by local architect and alderman James McDonald. The Anglican rectory and Catholic presbytery are two of the few outstanding residences erected in Rozelle during the late colonial period that have escaped demolition or alteration.

The public school, which John Horbury Hunt was invited to design, opened in 1878. William Edmund Kemp extended the original wing in 1884 and, under the hand of James Sven Wigram, it was extended again in 1901. In 1961, the school's Horbury Hunt wing survived an arson attack that destroyed much of the building's roof and flooring but left its fabric and structure undamaged. Using a free medieval style, local alderman and architect Edward John Bowen designed the adjoining St Paul's Presbyterian church, which opened in 1904.

Rozelle still has a Masonic hall, erected in Victorian classical style in 1888. The hall's elaborate facade includes a canopied life-size statue of Minerva, whose left hand holds up the beacon of learning for the enlightenment of nearby residents and the bustling pedestrians of Darling Street's northern thoroughfare. On the southwestern side of Darling Street stands the former fire station designed by Walter Liberty Vernon, an example of the domestic arts and crafts movement style for which Vernon is famed.

The 2008 rebirth of the former Mechanics' Institute in Victoria Road as a conservatorium of music is a welcome return to the original edifying purpose of this 1907 building, which was the advancement of useful arts. The building's previous life was mostly as a haven to a mouldy circulating library which was housed downstairs and numerous shady habitués who patronised the upstairs poolrooms. 
Other historic buildings have not survived. The early twentieth century rail sidings and wheat silos constructed on the Glebe Island reclamation displaced the Edmund Blacket-designed abattoirs, which were demolished in 1915. The removal in the mid-1950s of an entire row of imposing heritage buildings on the north-western side of Victoria Road for a wider carriageway took away the ornate towered Rozelle Post Office, designed by Vernon and built in 1893-94, the original weatherboard St Paul's (1876), designed by McDonald, Alexander Elphinstone's 1882 manse for St Paul's, and the original Bridge Hotel.

The White Bay Hotel, which dated from 1916, became a Glebe Island landmark. It was famed as Rozelle's sole 'early opener', with its public bar opening on weekdays at 6 am. After patronage evaporated in the wake of the closure or relocation of local heavy industry, the hotel ceased trading. At dawn on Saturday 6 September 2008, a fire that began the night before had completely razed the hotel, and another of Rozelle's iconic buildings was removed from the townscape.

\section{People and culture}

At home and at work, industrial life was masculine and hierarchical: foremen were subordinated to management, journeymen to foremen, and hands and apprentices to journeymen. Tent and street evangelism, spearheaded by the Methodist Church's open-air Helping Hand Mission and the Salvation Army, was the spiritual expression of social reform. Political expression thrived in the growth of the Labor Electoral Leagues, which were forerunners of the Australian Labor Party. Freemasonic and sectarian networks flourished and influenced political alliances as well as job preferment in the local workforce. Despite this, it was a Catholic resident of Rozelle, Mary Lilly May Quirk, who represented Balmain in the Legislative Assembly, serving from 1939 to 1950 as the second woman member and first Labor woman member of the New South Wales parliament.

Rozelle's births, deaths and marriages were registered at Balmain South. The electoral district was also known by the same name from 1894 to 1901.

A marriage solemnised in 1913 at the Methodist parsonage (now 750 Darling Street) and registered at Balmain South was that of widow Annie Birkett to Eugenia Falleni (1875-1938), who stood as the groom using the alias 'Harry Crawford'. In 1920, 'man-woman' Falleni was convicted of murdering Annie Birkett on the Eight-Hour Day holiday of 1917.

The finest historical organ left in Rozelle was built by Henry Jones and Sons of Kensington, London, for St Thomas's in 1884. In 1936, a choir member who helped organ-builder Charles Leggo relocate the organ from the church's south transept to its north was one John Kerr, later to become Governor-General of Australia.

Balmain fielded Rugby League teams as far back as 1908. The first licensed premises of Balmain Tigers, so called because of players' black-and-gold jerseys, occupied a former Mormon chapel on the northwestern side of Nelson Street in Rozelle. 
While Dr JJC Bradfield's vision of a Sydney Harbour Bridge became a reality in 1932, his plan of 1914-15 for the extension of an electric railway line connecting the city to Petersham via a bridge from Millers Point to the Balmain peninsula was dropped. Had the railway been constructed, Rozelle would have had two stations, Weston Road (now Victoria Road), and Callan Park (until recently known as Rozelle Hospital).

The pedestrian and cycle bridge at White Bay, which provides access from The Crescent to the Anzac Bridge via Victoria Road, was opened in December 2005 and named in honour of Mrs Beatrice Bush, who was reared at White Bay and for almost a quarter-century sold papers to motorists from a wheelbarrow parked on a Victoria Road traffic island. Wearing the distinctive Balmain Tigers football socks and trainers, Beatrice Bush was probably the last colourful character of Rozelle's interwar generation. She died in 1996, aged 72.

\section{Home to a creative class?}

American economist Richard Florida argues that an urban creative class is integral to the development of globalising knowledge economies. Such people are attracted to communities that foster an open, dynamic, personal, professional and innovative environment. This environment in turn attracts more creative people, as well as businesses and capital. Florida holds that attraction and retention of high-quality talent, rather than infrastructural projects (such as sports arenas, iconic buildings, and shopping malls), is the effective formula for urban regeneration and long-term prosperity. ${ }^{2}$

It is arguable that the Rozelle community of the twenty-first century exhibits characteristics of an evolving creative class in Florida's terms. If this is the case, the genesis of this class began around 1971, a year that marked a new generation of municipal politics, a community consciousness of heritage conservation, and public awareness of how deprived the area was of trees, open space, and other public amenities.

Relocation of maritime and heavy industry, a process that left an increasing number of vacant waterfront sites ripe for private investment in select residential development, was the catalyst of a later phase of local political and social history, the crucial episode of which occurred in 1992. In that year, State Planning Minister Robert Webster unilaterally approved a regional development plan that allowed high-rise high-density housing on Rozelle's adjoining Balmain Power Station and Monsanto Chemicals sites.

This contentious decision galvanised community opposition to large-scale residential development without proportionate provision of public open space. Rozelle's narrow thoroughfares were increasingly used as shortcuts for private and commercial vehicles travelling to and from the city, and there was widespread anxiety among residents that over-development of the disputed sites would produce unmanageable traffic in the Victoria Road artery. Backed by local popular support, Leichhardt Council challenged the decision in the New South Wales Land and Environment Court and lost. In response to popular indignation to the judicial decision (but acutely conscious of mounting legal costs), the council courageously chose to appeal. Much to ministerial chagrin, council won the appeal. 
This spirit of change, which Leichhardt Council's innovative open meetings had enlivened, was later captured in the documentary film Rats in the Ranks. The new political climate encouraged Aboriginal Senator Aden Ridgeway to establish his electoral office at White Bay.

The process of Rozelle's gentrification, together with corresponding socioeconomic and cultural change, is by no means complete. The number of women serving in local elected political office is tangible evidence of the extent to which 'chick-city' is at the forefront in facing the challenges and complexities of inner urban modernity.

John Williams is a writer

\section{Further reading}

Isadore Brodsky, Doctor David Ramsay: a sketch of his history and family, privately printed, Sydney, 1960

Bonnie Davidson, Kath Hamey and Debby Nicholls, Called to the bar: 150 years of pubs in Balmain and Rozelle, Balmain Association, Balmain NSW, 1991

Bonnie Davidson and Kath Hamey, Streets, lanes and places 1836-1994: an index of the origins of the street names of Balmain, Birchgrove and Rozelle, Balmain Association, Balmain NSW, 1994

Jeannie Gehue, 'Work and Community', Workers Online, no 9, 16 April 1999, http://workers.labor.net.au/9/c_historicalfeature_iron.html, viewed 30 August 2010

McDonald McPhee Pty Ltd, Craig Burton and Wendy Thorp, 'Heritage study of Leichhardt Municipality: study report', vols 1-3, Sydney, 1990

Craig Mear, 'The origin of the smallpox outbreak in Sydney in 1798', Journal of the Royal Australian Historical Society, vol 94 no 1, June 2008, pp 1-22

Phil Mosely, 'Factory Football: Paternalism and profits', University of Sydney Occasional Paper, undated

'St Thomas' Anglican Church Rozelle', Organ Historical Trust of Australia website, http://www.ohta.org.au/confs/Sydney/STTHOMASANGLICAN.html, viewed 30 August 2010

Peter L Reynolds and Paul V Flottman, Half-A-Thousand Acres: Balmain: A History of The Land Grant, Balmain Association, Balmain NSW, 1976

Max Solling and Peter Reynolds, Leichhardt: on the margins of the city: a social history of Leichhardt and the former municipalities of Annandale, Balmain and Glebe, Allen \& Unwin, St Leonards NSW, 1997

Garry Wotherspoon (ed), Sydney's transport: Studies in urban history, Hale \& Iremonger and the Sydney History Group, Sydney, 1983 


\section{Endnotes}

1 Lisa Pryor and Sherrill Nixon, 'All roads lead over bridge for city's single-minded', Sydney Morning Herald, 9 July 2003

2 Richard L Florida, The Flight of the Creative Class: The New Global Competition for Talent, HarperBusiness, HarperCollins, New York USA, 2005; Richard L Florida, Cities and the Creative Class, Routledge, New York USA, 2005 